\title{
The Impact of Internal and External Service Quality (A Case Study among Lecturers and Students)
}

Evi Susanti

Doctoral Student, Padjadjaran University, Bandung, Indonesia / Jakarta International College

Ernie Tisnawati Sule

Professor, Padjadjaran University, Bandung, Indonesia

Hilmiana Sutisna

Doctor, Padjadjaran University, Bandung, Indonesia

\section{Doi:10.5901/mjss.2015.v6n5s5p77}

\section{Abstract}

\begin{abstract}
Competition is becoming increasingly intense among private and public universities. Each university offers services to attract external customer, in this time we can call it; student. This study focuses on services in private universities have the same accreditation status. The purpose of this paper is to provide examination the impact of Internal Service Quality and External Service Quality. This research is provide examines services not only to students but also to the lecturers, who both need and get services. Lecturers are considered as internal customers and students as an external customers. This study uses SPSS 20.0 and test instruments have been carried out by using test reliability and validity and obtain results above 0.7 (Nunnally, 1978) and it considered valid is greater than 0.279 (Sugiama, 2008) then examine the relationship between variables using regression analysis. The findings of this study indicates Internal Service Quality has a positive significant and direct effect on External Service Quality. The papers show that educational service should focus on Internal Service Quality in order to improve External Service Quality
\end{abstract}

Keywords: Internal Service Quality, External Service Quality, Lecturers, Students, Educational Services

\section{Introduction}

Global competition level is very competitive because that business is facing unstable environment, economic condition uncertain and influence of fast changing technology, especially in the good and services industry. Challenging environment has fastest competition in the goods and services industry. Organization which can increase develop its strategy will get a champion in competition. The companies can be a winner in the competition if theycollaborate each other between the human capital and technological support that will execute strategy. Increasing company's performance if the company is able to create satisfaction in terms of both employees and consumers.

Many companies try to review their managerial patterns and to find basic solution so, they can access to be a competition advantage. Companies that can survive in the global competition is how company considers human capital running the company operations to achieve company goals for the companies need to consider how to provide services that are really needed employees so that they can actively participate in achievement objectives. Survival in competitive markets depends on how the company's delivered the services to employees through exceptional customer support to other service units within an organization (Dhurup, 2012)

Universities or academics institution need to innovate and create special features, innovate continuously and always understand and meet the needs of consumers will create customer satisfaction. Education has an important Operations of an university is determined also on how to regulate the internal order to effectively and efficiently run a good relationship with the owners, manager, employees, society and government. Recognition and permission of the government is one measure of the level of success of the company, in Indonesia is characterized by the recognition of "accredited".

Existence of universities are expected to print quality human resources. To prepare qualified human resources is needed reforms in education, one of them giving university autonomy. Since the enactment of the autonomy of higher 
education resulted in a growing number of emerging new private universities, even foreign universities took part in providing services and spur competition among higher education institutions to compete for students as consumers of services of formal education. With many private colleges (PTS), which sprung indirectly cause prospective students has more alternative options, thus making them more rational to choose the need for higher education services desired.

Competition in education services has fastest competitive, Factor such competitive forces may include among others: the strength of new comers, the strength of the education service users, their substitution products, power suppliers and competition among existing college. This study focus on the strength of the education services users. Relationship between internal and external quality in universities, in case management staff as an internal suppliers, lecturer as an internal customers and student as an external customers. Lecturer as an internal supplier to student within universities that receive services from employees and institution's, of service perceived by the faculty to meet their needs in supporting the improvement skills and espertise in its ability impact will provide services in the form of teaching better to students.

Student can learn activities with convenience environment as a professional lecturing, convenience places, technology and information equipment that supply management of higher education. Curriculum is very important to student performance. (Jain, et.al, 2011).Student who gives service felt satisfaction with the service quality. it has impact for increase student performance and ability. They have skills and abilities like output student who ready to work, have a soul of entrepreneurship, information technology skills and can compete in the global competition. Finally, role of internal service quality given the impact for external customers. Fromthis studies conducted above, it would interest us to know relationshipbetween lecturers as an internal customer and students as an external customers had examined the relationship between us. None of these studies was conducted in the Indonesian educational services. This has created a literature gap.

Therefore, the knowledge gap between services from lecturers and students in universities or academic institution in city of Jakarta, Indonesia. Dimensions of Internal service quality drawn Jain, Sinha\&Sahney, 2010 and the rule of educational Indonesian government as a curriculum, facilities, education, teaching, and research. The measures of literature External Service Quality are conceptualization adopted from Parasuraman et.al, 1988,1994. The dimensions of ESQ is this study are Tangibles, Emphaty Responsiveness, Reliability and Assurance.

\subsection{Problem Definition}

Education is a very important factor to improving the life of the nation. The importance of providing services for the students as an educational service users can influence the outcome of graduates who meet the needs of work, ability and have the skills that global competitiveness. The output can be generated from the quality of the lecturers who provide good teaching when universities provide facilities and services to support the advancement of knowledge and expertise.

\subsection{Objectives}

The study is to provide examination impact of Internal and External Service Quality. The specific objective to examine how the lecturers could give services to students and can influence to skills of global competitiveness.

\section{Literatur Review}

\subsection{Internal Service Quality in The Higher Education}

Sasser and Arbeit, 1976 who introduced term of employee asa internal customer thus Berry, 1990 view work as internal products and strive to offer products that satisfy internal customers and addressing and responding to organizational goals. The concept of internal service quality based on Hallowell, Schilesinger and Zomitsky, 1996, Pantouvakis, PanagiotisMpogatzis, 2012. Internal customers satisfaction has implication better services to external customers.

Internal service quality defined as sense of satisfaction felt by the internal customer from internal service providers I organization. (Hallowell, 1996).it is also supported by the waiter given by different organizational units or employees in the organizational unit to another unit or employee in organization (Stauss, 1995) in which the provider is charged with responding to the needs of their internal customers for professionalism (Randheer, 2015). Reynoso\&Moores, 1995 reveals that serve internal customers have impact on overall company performance.. According to the service profit chain perspective, the achievement of internal customer (employee) satisfaction is the basis for achieving excellent external customer satisfaction (Heskett, 1994). Emplyees who have been given good service, needs are met will be able 
to improve its services to external customers.(Vandermerwe and Gilbert, 1989; Heskett et.al, 1994).

In business service, the service personnel reflect the organizational realities. Through the interaction with the staff the customers form an opinion of the organization. A service organization may have all equipment and technical facilities, is the opinion was also developed Ghorbani\&Mostafavi, 2013, internal service quality is defined by Jones \&Silvestro, 2010 as the perceived quality of the services provided by different organizational units or people who work in this unit to other employees in the organization. Employees are well served needs showed its ability to serve customers. Khan, 2011, belief that internal customer can feel that the service provider has given its impact on employee satisfaction will improve the ability to better serve external customers. The principle of ISQ differentiated in 1) quality of service real (tangible) of internal services include training, incentive programs and employee welfare 2) the quality of intangible (intangible) as a access to the internal communication and level of autonomy for employees in power at work (Gao $\mathrm{Li}$ Wang, 2011). Further defined by Kumar, 2013, the internal service quality is a feeling that employees have to work, colleagues and company. Essentially external customers will be well served, if the internal consumer needs met first. Ganesh \&Haslinda, 2014, sees the importance of internal service quality that companies must effectively train and motivate employees as well as employees in other divisions to provide support so that it can work in a team to achieve customer satisfaction or Reynoso\&Moores, 1995 suggested that employees must receive good service from others within the organization in order to deliver good services to external customers as Bouranta\&Chirtis, 2008, considers the importance of internal service quality as it includes employees or departments within an organization acting as an internal supplier to the respond to both internal and external customers. Furthermore mean than an organization comprised of individual chains and functional units of customers, which in turn can improve organizational performance. (Gao Liang Wang, 2011).Suggested by Cardona,2012 that the implementation of internal service quality in higher education can be achieved only institutions can make environment and culturally appropriate as well as the attitude of the employee oriented best quality to customers. Concerned his research for $5 \mathrm{Q}$ (quality of courses, quality of teaching and learning, quality of infrastructure, quality of interaction between lecturers and students as well as the quality of environment. There is include education or research itself, deliver the object from lecturers and interaction and communication among staff.

Cheng, 2001 revealed that the most important thing is how employees are treated in institutions. not only measured from a given salary, but also of the environment and conditions of working. The journal Jeng\& Kuo,2012 defines internal service quality as the services provided by units of different organizations or employee in an institutions where the provider is charged with responding to the needs of internal customers. The human element is the most important element. The process reflects the reality through interaction between employees and customers form an opinion of the organizationit is through interaction between employees and customers. Service quality deliver internal to improve the quality of external services and emphasis customer satisfaction. Institutions may have all the facilities and technical equipment, but may not be able to provide satisfactory service to customers. Therefore, it becomes important for marketers service to motivate employees service customers better. The main requirement to motivate the employees to provide quality is to provide service quality to internal customers so that they can give high service quality for external customers.

\subsection{External Service Quality in The Higher Education}

Perceived and expected service quality in the company's services, especially higher education is the most important thing and concern higher education. Service culture is the soul of every member of the company. Services are categorized in two different things but the meaning and understanding of almost resembles.,Mosahab, et al,2010 naming "quality era". SERVQUAL research in the field of education has been wide used in education services, differences from previous studies that the study is to measure the fulfillment of lecturers to improve its services to students.

Services provided to employees are termed internal services and service provided to customers are termed with external services. The size is seen in how the company is able to provide good service to the employee so that the employee can provide services to consumers. The measure of SERVQUAL in higher education measurement of will see how the relationship between the services provided by the lecturer impact on perceived student services. The study of Ansory, Jayashree and Malavizhi, 2014 founding the difference of the consumer lies in their school, student and faculty members and different perspective. Two primary dimension of SERVQUAL according to. Jain, Sinha\&Sahney, 2011 which are 1) program quality: curriculum, industry interaction, input quality, academic facilities. 2) quality of life : non academic processes, support facilities, campus and interaction quality. This study is using different questionnaire to lecturer and students. Dimensions of service quality for lecturer considering Jain et.al 2011 and the rule of education law in Indonesia, and dimension of service quality for the students as an external customers using Parasuraman et.al, 1985. 
SERVQUAL have classified under two board categories; technical and functional (Gronroos, 1984; Parasuraman et.al., 1985,1988, 1991) it means that success of a student not only of intellectual skills but also supported by external factors such as learning materials, the quality of lecturers, library, facilities and infrastructure are also inadequate campus environment. While the quality of the lecturer supported by management staff provide facilities and opportunities for developing teaching abilities. Evaluation of students can improve the reliability of lecturers in teaching. (Palli\&Mamilla, 2012, Heskett, 1990, Tumar, 2014, Sharabi et.al, 2013).

Consistently services are provided to meet the expectations of consumers (Ghorbani, Mostafavi, 2013), External service quality defined as a fulfilling the needs and desires of customers and delivery accuracy in delivering value or benefis customers desired.

\subsection{Relationship between Internal and External Service Quality in Higher Education}

Relationship both internal and external service quality is depends on how your services rendered. Employees will serve in earnest when they are satisfied by service companies, and consumers will be satisfied if the services provided by the employees very well. An analysis of the services within Higher Education institutions reveals that the services provided to students coming from all the good elements of the lecturer, leadership and staff, all of whom have ties that need each other. (Sharabi\&Yezreel, 2013). Many research using two groups ; teachers as a internal customers and students as a external customers (Snipes, 1999, Palli, 2012. Services that may adversely impact on the perception of the instiutionwoul not be happy with the result of a boring lecturer, have limited knowledge or not up to date, poor administrative support from academic departments, deans and management staff. It also supported by research Mosahab, Mahamad \& Ramayah, 2010, found a negative relationship between faculty and students because of the responsibility and the dimensions of tangibility.

An improvement of service perceived effect on the quality of teaching and its impact on the quality of student services may be an increase in the CPI changes in behavior and attitudes. In college business focus is on service to internal and external customers, while the focus of profitability, productivity and efficiency are the focus of a second after the first focus met. (Snipes \& Thomson, 1999).

\section{Methodology}

This research carried out on 2015 within 2 universities or academic institution of Jakarta-Indonesia. Questionnaire was made and developed of two different forms. The first part, a questionare distributed to lecturer Five dimensions of ISQ are adopted from Jain, Sinha\&Sahney, 2010 and the rule of education government. The second part elicited sampels students type importance scale ranging from "very important" to "not important at all.". Measuring ESQ adopted from Parasuraman 1988, 1994 and Palli\&Mamilla, 2012 consisitng of 20 items.

From a total 115 questionnaires distributed, 100 questionaires had been filled in correctly and completely. Nevertheless they found 15 questionaire assessed invalid. Approach to individual respondents conducted in distributing questionnaires. The response of respondents is relatively high response rate was. Respondents were selected from two universites or academic institutions with the same grades. Purposive sampling method used in this study. Student in question is already been enjoying the services of at least one semester ; the lecturer has taught at the college for at least one year. The response of respondents is relatively high at two universities. The questionnaires were distributed during in his spare time as a change of course. This research is focused to find out the determinants of services redered institutions.

Data is collected and codified to the statistical package for social sciences (SPSS) version 20.0. the data is analyzed, in this section of the research. Measuring reliability and validity usingCronbach's alpha coefficient, internal service quality was 0.72 and external service quality was 0.798 . Recommended by Nunnally, 1978 is above 0.7 .

According Sugiama, 2008 an item is valid, if the corrected item total correlation value is above the value of $r$ product moment and for the value of $n=50 a=0.05$ equal to 0.279 . The qinstrumentsare valid because validity for Internal service quality between $0.29-0.57$ and External Service Quality between $0.31-0.59$ Secondly, a regression analysis was used to measure the impact of internal and external service quality.

\section{Findings}

The findings of this study are shown in Table I reveals that 68.3 percent of the external service quality is influenced by the variable internal service quality and the rest influenced by other variables that are assumed to be ignored. This means 
that students perceived service as lecturers provide services. These services include five dimensions of Parasuraman et.al. $(1988,1994)$. and the internal service quality using five dimensions are adopted from Jain, Sinha\&Sahney, 2010 and the rule of education government.

Table 1. Model Summary

\begin{tabular}{|c|c|c|c|c|}
\hline Model & $\mathrm{R}$ & $\mathrm{R}$ Square & Adjusted R Square & Std. Error of the Estimate \\
\hline 1 &, $826^{\mathrm{a}}$ &, 683 &, 676 &, 18578 \\
\hline
\end{tabular}

a. Predictors: (Constant), Internal Service Quality

Table 2. ANOVAa

\begin{tabular}{|l|c|c|c|c|c|}
\hline Model & Sum of Squares & Df & Mean Square & F & Sig. \\
\hline Regression & 3,570 & 1 & 3,570 & 103,441 &, $000^{\mathrm{b}}$ \\
$1 \mid$ Residual & 1,657 & 48 &, 035 & & \\
$\mid$ Total & 5,227 & 49 & & & \\
\hline
\end{tabular}

a. Dependent Variable: kualext

b. Predictors: (Constant), Internal Service Quality

Because the only measure of influence between two variables, so the ANOVA table is ignored, ANOVA table is used to look at the effect of simultaneous.

Table 3. Coefficients ${ }^{\mathrm{a}}$

\begin{tabular}{|l|c|c|c|c|c|}
\hline \multirow{2}{*}{ Model } & \multicolumn{2}{|c|}{ Unstandardized Coefficients } & Standardized Coefficients & \multirow{2}{*}{ S } & \multirow{2}{*}{ Sig. } \\
\cline { 2 - 5 } & $\mathrm{B}$ & Std. Error & Beta & & \\
\hline 1 (Constant) &,- 560 &, 375 & & $-1,492$ &, 142 \\
\hline ISQ & 1,159 &, 114 &, 826 & 10,171 &, 000 \\
\hline
\end{tabular}

a. Dependent Variable: External Service Quality

Significant effect on the quality of internal service quality with significant value of 0.000 means significant at $99 \%$ confidence level.

Table 4. Descriptive Statistics

\begin{tabular}{|c|c|c|c|}
\hline & Mean & Std. Deviation & N \\
\hline ESQ & 3,2470 &, 32661 & 50 \\
\hline ISQ & 3,2840 &, 23287 & 50 \\
\hline
\end{tabular}

Length class (5-1)/5 =0,8 then

1 - 1.799: not good

$1,8-2,599$ : less good

$2,6-3,399:$ pretty good

$3,4-4,199:$ good

$4,2-5,00$ : very good

With these criteria, then the average internal service quality and external service quality, including good enough category. Standard maximum deviation of $20 \%$ multiplied by the mean value so standard maximum deviation to the variable internal service quality was $20 \% \times 3.28=0.66$ and the variable external service quality is 0.65 . Standard deviation means that thelecturers perception about the internal services quality and external service quality is not so varied or almost the same. 


\section{Discussion, Conclusion and Implications}

Based on the summary of findings, we arrived at the following conclusions. Our study revealed that is a significant relationship between perceived of service lecturers with perceived students. The meaning of that, if the lecturers are well served by the institution management, they can serve students very well. Dimensions adopted of this research from Jain, Sinha\&Sahney, 2010 and the rule of education government. The survey conducted, lecturers are still unsatisfied with the services, especially in the dimension of education and research. The lack of support from institution management as lecturer less encouraged to follow higher education, universities rarely provide trainings and conduct research faculty was not facilitated. Dimensions average facilities and curriculum is good.

While the students still feel less get faculty on the dimensions of service assurance and responsibilities, as a lecturer has not provided examples of cases which is up to date, on the other hand, the average answer that lecturers seldom work exams students. While for tangible dimension, empathy and reliabilities average good.

Institution management should provide a good service to the faculty, especially in the dimension of education and research, by providing scholarships and provides funding for training and research. This adversely affects the performance of lecturers will result in low performance of the colleges. With the trainings and improving education and the amount of research, lecturers have extensive knowledge and implication of a recent case examples.

Communication and information technology is one of the factors determine the success of the service. Its use in the form of delivering lecturers. Submit assignments, speed information, the relationship between faculty, administrative staff and students changing patterns of teaching today is more on how technology and the information used in the communication in the learning process and speed up the services.

The higher education looked at importance of human capital (lecturer) as one that can produce graduates who have the skills and competency useful both for the individual and the state. In the global competition is not just how to recruit students but also how to get lecturers who have the competencies that meet the law on teachers and lecturers in Indonesia. Studies confirm that the higher education sector can be considered a marketplace and university education a marketable service. Universities realize that they are business entities and like others they must compete for resources and customers or students, both in the local and international market( Sultan \& Wong, 2010, Min \&Khoon, 2013).

\section{References}

Amin Ansory, Sreemivasan Jayahree, "The Effect of Gender and Nationality on Service Quality in Malaysian Higher Education", The Journal of Developing, 2014

Bouranta Nancy \& Leonidas Chitiris" The Relationship Between Internal and External Service Quality", International Journal of Contemporary Hospitality Management, 2008

Berry, L.L, Zeithaml, V.A and Parasuraman, A, "Five imperatives for improving service quality", Sloan Management Review, 1990

Berry L.L., "The Employee as a Customer", J Retail Bank, 1981

Cardona Madeline Melchor, Y Juan Jose Bravo, "Service Quality Perceptions in Higher Education Institutions : The Case of a Colombian University", EstudiosGerenciales, 2012

Dhurup M, "Determinants of Internal Service Quality and The Relationship With Internal Customer Satisfaction", African Journal of Business Management, 2012

Deepika Singh Tomar, "A Comparative Study of Service Quality Perception Between Public and Private Sector in The Indian Higher Education System", Pezzottaite Journals,2014

Ghassan R.Odeh \& Hamad R.Alghaedeer, "Organizational Commitment as a Mediator Variable on The Relationship between The Internal Marketing and Internal Service Quality : An Empirical Study of Five Star Hotels in Amman", International Journal of Marketing Studies, 2014

Ghorbani Hassan, Maedeh Mostafavi, "Direct and Indirect of Internal Marketing on Service Quality and Mediating Role of OCB, CASE : Iran Insurance Company", International Journal of Academic Research in Business and Social Science, 2013

Ganesh R \&Haslinda A., Evolution and conceptual development of service quality, service marketing and customer satisfaction, International Review of Management and Business Research. 2014

Gao Liang Wang, "A Study of How The Internal-Service Quality of International Tourist Hotels Affects Organizational Performance : Using Employee's Job Satisfaction as the Mediator,",2011

Grönroos, C. "A Service Quality Model And Its Implications", European Journal of Marketing, 1984.

Grönroos, Christian, "Service Management and Marketing", Lexington Books, Lexington, MA, 1990.

Hallowell, Roger, Schlesinger, Leonard A: Zomitsky, Jeffery, "Internal Service Quality, Customer and Job Satisfaction :Lingkages and Implications for Management, HR Planning; 1996: 19,2 ; Proquest,1996

Heskett, James, Sasser, W.,Earl and Hurt, CWL, "Service Breakthoughs", New York ; The Free Press, 1990

Jain Rajani, Gautam Sinha, "Conceptualizing Service Human Resources Quality in Higher Education" Asian Journal on Quality, 2011

Jones-Alistair Brandon, Rhian Silvestro, "Measuring Internal Service Quality : Comparing The Gap-Based and Perceptions-Only 
Approaches, International Journal of Operation and Production Management, 2010

Kokku Randheer, "Service Quality Performance Scale in Higher Education : Culture as a Dimension", International Business Research, 2015

Mosahab, Rahim, Osman Mahamad, T.Ramayah, "Comparison of Service Quality Gaps Among Teachers and Students as Internal and External Customers" 2010

Moshe Sharabi, "Managing and Improving Service Quality in Higher Education", International Journal and Service Science", 2013

Maria Jesus Martinez-Arguelles, Miguel Blanco Callejo, Jose M Castan Farrero,"Dimensions of Perceived Service Quality in Higher Education Virtual Learning Environment", RUSC 2013

Muhammad Asif Khan et.al., "Modeling Link Between Internal Service Quality in Human Resources Management and Employees Retention : A case of Pakistan Privatized and Public Sector Bank", African Journal of Business Management, 2011

Nunnally, J. Psychometric theory.Englewood-Cliffs, NJ, McGraw-Hill Book Company, (1978)

Palli Janardhana Gundla, \&Rajasekhar Mamilla, "Students Opinions of Service Quality in The Field of Higher Education", Scientific Research, 2012

Parves Sultan and Ho Yin Wong, "Service Quality in Higher Education-A Review and Research Agenda", International Journal of Quality and Service Sciences, 2010

Parasuraman, A; Berry, Leonard L; Zeithaml Valarie A., "Perceived Service Quality as a Customes-Based Performance Measure : An Empirical Examination of Organizational Barriers Using an Extended Service Quality Model", Human Resources Management , ABI/INFORM Complete, 1986-1998

Parasuraman, A., Zeithaml, Valarie. A. and Berry, L. Leonard, "SERVQUAL: A multiple-item scale for measuring consumer perceptions of service quality", Journal of Retailing, 1988

Parasuraman, A, Zeithaml, V. A., \& Berry, L. L. "Alternative scales for measuring service quality: A comparative assessment based on psychometric and diagnostic criteria", Journal of Retailing, 1994

Pantouvakis, Angelos, "Internal Service Quality and Job Satisfaction Synergies for Performance Improvement : Some Evidence from a B2B Environment, Journal of Targeting, Measurement and Analysis for Marketing, 2011

Pantouvakis, Angelos, PanagiotisMpogiatzidis, " The Impact of Internal Service Quality and Learning Organization, on Clinic Leaders' Job Satisfaction in Hospital Care Services, Emerald Group Publishing Limited, 2013

Parves Sultan \& Ho Yin Wang, "Service Quality in Higher Education-a Review and Research Agenda" International of Quality and Service Science", 2010

RandheerKokku, "Service Quality Performance Scale in Higher Education : Culture as a New Dimension", International Business Research, 2015

Reynoso, Javier ; Moores, Brian, " Towards The Measurement of Internal Service Quality", International Journal of Service Industry Management, 1995

RobbinL.Snipes \& Neal Thomson, "An Empirical Study of The Factors Underlying Student Service Quality Perceptions in Higher Education, Alled Academies National Conference, 1999

Sharabi Moshe, "Managing and Improving Service Quality in Higher Education" International Journal of Quality and Service Sciences, 2013

Sasser, W \&Arbeit, S, "Selling Jobs in The Service Sector", Business Horizons, 1976

Sein Min, \& Chey Chor Khoon, "Demographic Factors in The Evaluation of Service Quality in Higher Education : International Students' Perspective, International Review of Management Business Research, 2013

Sein Min \& Chey Chor Khoon, "Demographic Factors in The Evaluation of Service Quality in Higher Education : International Student's Perspective", 2013

Sugiama, Gima, "MetodeRisetBisnisdanManajemen, EdisiPertama, Guardayalntimarta, Bandung, 2008

Stauss B, Seidel W, " Discovering the Customer Annoyance Iceberg through Evidence Controlling" Serv.Bus 2, 2008 :

Stauss B, "Internal services: classification and quality management". Int J ServlndManag, 1995

Vauterin Johanna Julia ,Lassi Linnanen and Esa Martila, "Issues of Delivering Quality Customer Service in a Higher Education Environment", International Journal of Quality and Service Sciences, 2011

Zeithmal, Valarie A; Berry, Leonard L;Parasuraman, "The Behavioral Consequences of Service Quality" Journal Marketing, 1996 